Reprinted with permission from: Weed Technology. 1998. Volume 12:602-609.

Published and copyrighted by: Weed Science Society of America. http://www.wssa.net

\title{
Leafy spurge (Euphorbia esula) response to AC 263,222
}

\author{
ROBERT A. MASTERS, DANIEL D. BERAN, and FERNANDO RIVAS-PANTOJA \\ Rangeland Scientist, United States Department of Agriculture, Agricultural Research Service; Graduate Research As- \\ sistants, Department of Agronomy, University of Nebraska, Lincoln, NE 68583.
}

\begin{abstract}
:
Leafy spurge is an exotic perennial weed that infests more than 1 million ha in North America and reduces rangeland carrying capacity. Experiments were initiated on range sites in Nebraska and North Dakota in 1994 and 1995 to determine the response of leafy spurge and other vegetation to AC 263,222. Herbicide treatments evaluated included AC 263,222 at 0 to $280 \mathrm{~g}$ ai/ha, picloram at $560 \mathrm{~g}$ ai/ha plus 2,4-D at 1,120 $\mathrm{g}$ ae/ha, and quinclorac at 1,120 g ai/ha. In Nebraska, a single application of AC 263,222 in the fall at $140 \mathrm{~g} /$ ha provided $\geq 90 \%$ leafy spurge control 11 to 12 months after treatment. At Jamestown, ND, leafy spurge control increased to almost $90 \%$ and stem density declined to two shoots $/ \mathrm{m}^{2} 12$ months after the second consecutive fall application of AC 263,222 at $140 \mathrm{~g} / \mathrm{ha}$. At Hankinson, ND, leafy spurge control was $\leq 50 \%$ when AC 263,222 was applied in the fall only, but increased to $>80 \%$ when AC 263,222 was applied in the fall and again at 70 or $140 \mathrm{~g} / \mathrm{ha}$ in the spring. There were no differences in herbage biomass of established cool- and warm-season grasses where AC 263,222 at $140 \mathrm{~g} /$ ha, picloram plus 2,4-D, quinclorac, or no herbicide was applied in the fall. In contrast, application of AC 263,222 in the fall and again in the spring usually reduced cool-season grass biomass.
\end{abstract}

\section{Nomenclature:}

AC 263,222, ( \pm )-2-[4,5-dihydro-4-methyl-4-(1-methylethyl)-5-oxo-1Himidazol-2-yl]-5-methyl-3-pyridinecarboxylic acid; picloram, 4-amino3,5,6-trichloro-2-pyridinecarboxylic acid; quinclorac, 3,7-dichloro-8-

\footnotetext{
${ }^{1}$ Received for publication February 13, 1998, and in revised form July 13, 1998. Contribution 12298, Agriculture Research Division, University of Nebraska, Lincoln, and the USDA-ARS.
} 
quinolinecarboxylic acid; 2,4-D, (2,4-dichlorophenoxy)acetic acid; leafy spurge, Euphorbia esula L. \#² EPHES.

\section{Additional index words:}

Rangeland, perennial grasses, imidazolinone herbicides, perennial weed control, warm-season grasses, cool-season grasses, forbs, EPHES.

\section{Introduction}

Leafy spurge (Euphorbia esula L.) is a serious threat to the productivity of central and northern Great Plains rangeland. Leafy spurge was estimated to infest about 1 million ha in North America in 1979 (Dunn 1979). This invasive weed reduces the quality of rangeland by interfering with desirable native species (Belcher and Wilson 1989), reducing livestock carrying capacity, and lowering the quality of wildlife habitat. Herbicides are one of the primary tools used to manage leafy spurge infestations.

Leafy spurge control with herbicides is variable. Picloram and 2,4-D are the most commonly recommended herbicides to control leafy spurge. Picloram at $2.2 \mathrm{~kg} / \mathrm{ha}$ can provide good leafy spurge control for up to 36 months (Lym and Messersmith 1985). The high cost and restrictions in the maximum amount of picloram that can be applied to a given area limits the use of this treatment to small patches of leafy spurge. For large infestations, 2,4-D plus picloram at 1,120 plus $280 \mathrm{~g} /$ ha or 2,4-D alone at 2,240 g/ha is commonly recommended. However, these treatments provide only short-term leafy spurge control. Another drawback of picloram and 2,4-D is the adverse effect these herbicides have on desirable broadleaf species growing in leafy spurge infestations. Quinclorac provides short-term leafy spurge control (Kuehl and Lym 1997), but is not registered for use on noncropland, rangeland, or pastures.

The imidazolinone herbicides, imazapyr $\{2-[4,5-$ dihydro-4-methyl-4-(1-methylethyl)-5-oxo-1H-imidazol-2-yl]-3-pyridinecarboxylic acid $\}$, imazethapyr $\{2-[4,5-$ dihydro-4-methyl-4-(1-methylethyl)-5-oxo-1H-imidazol-2-yl]-5-ethyl-3-pyridinecarboxylic acid\}, and imazaquin \{2-[4,5-dihydro-4-methyl-4-(1-methylethyl)-5oxo-1H-imidazol-2-yl]-3-quinolinecarboxylic acid\}, control leafy spurge (Masters et al. 1994). Leafy spurge control with these herbicides applied at $280 \mathrm{~g} / \mathrm{ha}$ in the fall was similar to that of fall-applied picloram and spring-applied 2,4-D. Phytotoxic effects of the imidazolinone herbicides to leafy spurge results from high absorption, preferential translocation to roots and adventitious shoot buds, and slow rate of metabolism (Nissen et al. 1994, 1995; Thompson et al. 1996, 1998). AC 263,222 is an imidazolinone herbicide that may control leafy spurge. The objectives of this research were (1) to determine the response of leafy spurge to AC 263,222 applied at various rates in the fall and/or spring, (2)

\footnotetext{
${ }^{2}$ Letters following this symbol are a WSSA-approved computer code from Composite List of Weeds, Revised 1989. Available from WSSA, 810 East 10th Street, Lawrence, KS 66044-8897.
} 
to determine the effect of AC 263,222 on other vegetation on leafy spurge-infested sites, and (3) to compare efficacy of AC 263,222 with picloram plus 2,4-D and with quinclorac.

\section{Materials and methods}

Five field experiments were initiated at sites near Jamestown, ND, in 1994, Ainsworth, NE, in 1994 and 1995, and at Hankinson, ND, and Tilden, NE, in 1995. Soils at the sites ranged from a sand to a silt loam (Table 1). Experimental plots were 5- by 8-m in size and were separated by 1- to 2-m wide borders that were not treated with herbicide. Each experiment was designed as a randomized complete block with three or four replications per herbicide treatment.

Table 1. Selected characteristics of soils at research sites.

\begin{tabular}{lllcc}
\hline Site location & \multicolumn{1}{c}{ Soil series } & \multicolumn{1}{c}{ Soil classification } & Organic & $\begin{array}{c}\text { Orgatter } \\
\text { matr }\end{array}$ \\
\hline Ainsworth, NE & Tryon loamy fine sand & Sandy, mixed, mesic, Typic Psammaquent & 6.2 & 1.7 \\
Hankinson, ND & Glyndon silt loam & $\begin{array}{l}\text { Coarse-silty, mixed, frigid, Aeric } \\
\text { Calciaquoll }\end{array}$ & 7.8 & 5.8 \\
Jamestown, ND & Fordville loamy sand & $\begin{array}{l}\text { Fine loamy over sand or sandy } \\
\text { skeletal, mixed Pachic Udic Haploboroll }\end{array}$ & 6.8 & 6.8 \\
Tilden, NE & Thurman fine sand & $\begin{array}{l}\text { Sandy, mixed, mesic, Udorthentic } \\
\text { Haplustoll }\end{array}$ & 6.2 & 2.6 \\
\hline
\end{tabular}

Jamestown, ND. This experiment was conducted on an overflow range site adjacent to Pipestem Lake, which is managed by the U.S. Army Corps of Engineers. Leafy spurge and Kentucky bluegrass (Poa pratensis L. \# POAPR) were the dominant species. AC 263,222 at 140 and $280 \mathrm{~g} /$ ha and picloram at $560 \mathrm{~g}$ ai/ha plus 2,4-D at 1,120 g/ha were applied to separate plots on August 31,1994, and to the same plots again on September 26, 1995.

Ainsworth, NE, 1994. The research site was located on a naturally subirrigated range site where the botanical composition was diverse and heterogeneous. Cool-season grasses included Kentucky bluegrass, smooth brome grass (Bromus inermis L. \# BROIN), redtop bent (Agrostis stolonifera L. \# AGSST), and timothy (Phleum pratense L. \# PHLPR). Warm-season grasses included big bluestem (Andropogon gerardii Vitman \# ANOGE), indiangrass [Sorghastrum nutans (L.) Nash], switchgrass (Panicum virgatum L. \# PANVI), little bluestem [Schizachyrium scoparium (Michx.) Nash \# ANOSC], and prairie cordgrass (Spartina pectinata Link \# SPTPE). Leafy spurge was the dominant broadleaf species and red clover (Trifolium pratense L. \# TRFPR), lead plant (Amorpha canescens Pursh \# AMHCN), and yarrow (Achillea millefolium L. \# ACHMI) were common. AC 263,222 at 0, 140, 210, and $280 \mathrm{~g} /$ ha and quinclorac at 1,120 g/ha were applied on September 28, 1994, and October 18, 1995. Picloram at $560 \mathrm{~g} /$ ha plus 2,4-D at $1,120 \mathrm{~g} /$ ha was applied on June 21 and October 18, 1995. AC 263,222 at 140 and 210 $\mathrm{g} /$ ha was applied on June 21, 1995, and again on June 18, 1996, to half of the plots that 
had been treated with AC 263,222 at 140 and $210 \mathrm{~g} /$ ha, respectively, in the fall of 1994 and 1995. In addition, AC 263,222 at 140 and $210 \mathrm{~g} /$ ha was applied on June 21, 1995, and again on June 18, 1996, to plots that had not been treated with herbicide in the fall. Plots were retreated the second year of the experiment with same treatments that had been applied the first year.

Ainsworth, NE, 1995. This experiment was conducted at a different location, but on the same subirrigated range site as the experiment initiated at Ainsworth in 1994. At this location, Kentucky bluegrass, prairie cordgrass, and leafy spurge were the dominant species. This experiment was designed as a randomized complete block with four replications. Treatments were arranged as a factorial with four rates of AC 263,222 $(0,140,210$, and $280 \mathrm{~g} / \mathrm{ha}$ ) applied on October 18, 1995. AC 263,222 at $70 \mathrm{~g} / \mathrm{ha}$ was applied on June 18,1996 , to half of the plots that had been treated with the four AC 263,222 rates in October 1995 .

Hankinson, ND. The research site was a remnant tall-grass prairie that was part of the Prochnow Waterfowl Production Area managed by the USDI, Fish and Wildlife Service. Cool-season grasses included Kentucky bluegrass, needle-and-thread (Stipa comata Trin. \& Rupr. \# STDCO), and smooth bromegrass. Warm-season grasses included big bluestem, switchgrass, indiangrass, little bluestem, and prairie cordgrass. Leafy spurge was the dominant broadleaf species and black medic (Medicago lupulina L. \# MEDLU) and red clover were common. Treatments were arranged as an augmented factorial (Federer and Raghavarao 1975) with four rates of AC 263,222 (0, 140, 210, and 280 $\mathrm{g} / \mathrm{ha}$ ) and an augmented treatment of quinclorac at 1,120 g/ha applied on September 27, 1995. Two rates of AC 263,222 at 70 and $140 \mathrm{~g} /$ ha were applied on June 26, 1996, to half of the plots that had been treated with the four AC 263,222 rates in September 1995.

Tilden, NE. This experiment was conducted on a degraded sands range site where Kentucky bluegrass, blue grama [Bouteloua gracilis (H.B.K.) Lag. ex Steud.] and leafy spurge were dominant. Treatments were arranged as an augmented factorial with four rates of AC 263,222 (0, 140,210, and $280 \mathrm{~g} / \mathrm{ha})$ and the augmented treatments (quinclorac at $1,120 \mathrm{~g} / \mathrm{ha}$ and picloram at $560 \mathrm{~g} / \mathrm{ha}$ plus 2,4-D at 1,120 g/ha) applied October 11,1995 . AC 263,222 at $70 \mathrm{~g} /$ ha was applied on June 17, 1996, to half of the plots that had been treated with the four AC 263,222 rates in October 1995.

In all experiments, herbicide spray solutions were applied with a tractor-mounted sprayer using compressed air at $230 \mathrm{kPa}$ to deliver $190 \mathrm{~L} / \mathrm{ha}$. AC 263,222 and quinclorac were applied with methylated sunflower seed oil ${ }^{3}$ and $28 \%$ urea ammonium fertilizer each at $1.25 \%(\mathrm{v} / \mathrm{v})$. Leafy spurge and cool-season grasses were past flowering and growing, and warm-season grasses were dormant when herbicides were applied in the fall. Leafy spurge was flowering, cool-season grasses were at boot stage or headed, and warm-season grasses were vegetative when herbicides were applied in late spring to early summer.

The research sites were not grazed or hayed for the duration of the study. Sites were burned using procedures described by Masters et al. (1990) on May 15 at Ainsworth, June 11 at Jamestown, June 6 at Hankinson, and May 17 at Tilden in 1996. Sites were

\footnotetext{
${ }^{3}$ Sunit II. AGSCO, Inc., Grand Forks, ND 58208-3458.
} 
burned to remove standing dead herbage, which would otherwise interfere with vegetation sampling in late summer.

Leafy spurge response to herbicide treatments was determined by measuring control, shoot biomass, and shoot density. Leafy spurge visual control ratings were made using a scale of 0 (no control) to $100 \%$ (complete control) 11 to 12 months after application of fall treatments.

Biomass of selected components of the vegetation was measured starting in August and September 1995 for experiments initiated at Ainsworth and Jamestown in 1994, respectively, and in August 1996 for all experiments. Biomass was determined by harvesting vegetation within two $0.25-\mathrm{m}^{2}$ quadrats located within each 8 - by $5-\mathrm{m}$ plot. Vegetation within each quadrat was clipped to a 2- $\mathrm{cm}$ stubble height and separated into the following vegetation categories: leafy spurge, warm-season grasses, cool-season grasses, and forbs (broadleaf plants other than leafy spurge). Harvested vegetation was oven-dried at $60^{\circ} \mathrm{C}$ for 72 hours and weighed. Leafy spurge density was determined in September 1995 at Jamestown and for all experiments in August 1996 by recording the number of live leafy spurge shoots within quadrats placed in each plot just before vegetation harvest.

Data from each of the five experiments were analyzed separately using the general linear model procedure (SAS 1990). Leafy spurge control ratings were analyzed as percentages and transformed (arcsine of the square root) percentages. Results from analysis of transformed control data were no different from that of the nontransformed data; therefore, nontransformed control data are presented. Data collected in 1995 and 1996 from experiments initiated at Jamestown or Ainsworth in 1994 were not pooled across years because error variances for most measured attributes were determined to be heterogeneous according to Hartley's F-max test (Ott 1977). Treatment means of measured attributes were compared using Fisher's protected LSD test $(\alpha=0.05)$. In experiments initiated in 1995, the main effects and interaction of fall and spring application dates of AC 263,222 were evaluated. For ease of data presentation, Fisher's protected LSD test ( $\alpha=$ $0.05)$ was used to compare significant $(\mathrm{P} \leq 0.05)$ main effect and interaction treatment means and to compare augmented (Federer and Raghavarao 1975) picloram plus 2,4-D and/or quinclorac treatments with AC 263,222 treatments where appropriate.

\section{Results and discussion}

Annual precipitation at National Oceanographic and Atmospheric Administration weather monitoring stations located within $15 \mathrm{~km}$ of the research sites was usually above the 30-year average for the duration of the study (Figure 1). At Jamestown, annual precipitation ranged from 29 to $235 \mathrm{~mm}$ above the long-term average of $422 \mathrm{~mm}$ during the experiment. Precipitation was above normal in March, April, and May 1995, which led to a portion of the site being flooded for a 45-day period starting in late May 1995. At Ainsworth, precipitation was within $30 \mathrm{~mm}$ of the average $(547 \mathrm{~mm})$ in 1994 and 1996 and $195 \mathrm{~mm}$ above average in 1995. At Tilden, the precipitation was $186 \mathrm{~mm}$ above and 78 mm below average $(648 \mathrm{~mm})$ in 1995 and 1996, respectively. In 1995 and 1996, precipitation was $45 \mathrm{~mm}$ above and $42 \mathrm{~mm}$ below average (543 $\mathrm{mm}$ ), respectively, at Hankinson.

Page 5 of 12 
Figure 1. Average monthly precipitation during the study near Ainsworth and Tilden, NE, and Jamestown and Hankinson, ND.

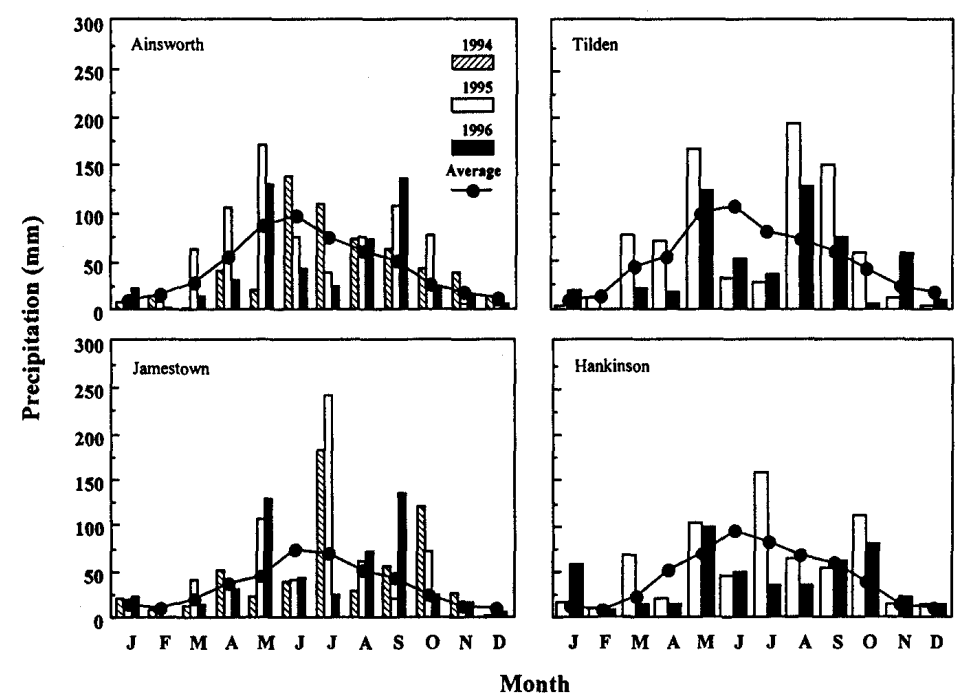

Jamestown, ND. Excessive precipitation in the spring of 1995 caused two of the four replications of each herbicide treatment to be flooded from late May through mid-July. The flooding did not interfere with assessment of the response of leafy spurge and the other resident vegetation to AC 263,222 or picloram plus 2,4-D. Data were analyzed and the effect of the flooding was partitioned into the block source of variation and did not contribute to the variation associated with herbicide treatments. This event provided a unique opportunity because leafy spurge often occurs in riparian areas that are subjected to periodic inundation; therefore, the assessment of AC 263,222 efficacy and stability under flood conditions was valuable.

In 1995, leafy spurge control was greatest (90\%) with AC 263,222 at $280 \mathrm{~g} / \mathrm{ha}$ compared with all other treatments (Table 2). AC 263,222 at $140 \mathrm{~g} /$ ha provided better control of leafy spurge than picloram plus 2,4-D. Leafy spurge density was lowest where AC 263,222 was applied at $280 \mathrm{~g} /$ ha compared with areas treated with AC 263,222 at 140 $\mathrm{g} /$ ha or picloram plus 2,4-D.

In 1996, after two consecutive years of herbicide application, AC 263,222 at 140 or $280 \mathrm{~g} /$ ha provided at least $89 \%$ leafy spurge control compared with only $34 \%$ control with picloram plus 2,4-D (Table 2). Leafy spurge density was greatly reduced following two consecutive years of application of AC 263,222 at $140 \mathrm{~g} / \mathrm{ha}$. In contrast, density on picloram plus 2,4-D-treated plots was the same as areas that were not treated with herbicide and greater than the density on areas treated with either rate of AC 263,222. Leafy spurge biomass was less where AC 263,222 was applied than where picloram plus 2,4-D was applied.

Kentucky bluegrass, the only cool-season grass on the site, was not adversely affected by the herbicides and produced an average of $3.8 \mathrm{Mg} / \mathrm{ha}$ in 1995 and $1.6 \mathrm{Mg} / \mathrm{ha}$ in 1996 . This reduction in biomass from 1995 to 1996 resulted from differences in amount of standing dead grass herbage each year. The Kentucky bluegrass had not been burned or hayed for several years before this experiment was initiated. This resulted in an accumulation of dead herbage, which was harvested with the current year's production in 1995. 
In contrast, only the current year's production of Kentucky bluegrass was sampled in 1996 because standing dead herbage had been removed by burning.

Table 2. Leafy spurge control, shoot density, and shoot biomass in September 1995 and August 1996 after fall application of herbicides on a range site near Jamestown, ND.

\begin{tabular}{|c|c|c|c|c|c|c|c|}
\hline \multirow[b]{2}{*}{ Herbicide } & \multirow[b]{2}{*}{ Rate $^{a}$} & \multicolumn{2}{|c|}{ Control } & \multicolumn{2}{|c|}{ Density } & \multicolumn{2}{|c|}{ Biomass } \\
\hline & & 1995 & 1996 & 1995 & 1996 & 1995 & 1996 \\
\hline & g ai/ha & 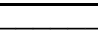 & 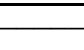 & $\overline{-1}$ & & - & $1-$ \\
\hline No herbicide & 0 & 0 & 0 & 91 & 174 & 1,170 & 380 \\
\hline AC 263,222 & 140 & 66 & 89 & 66 & 2 & 80 & 0 \\
\hline AC 263,222 & 280 & 90 & 99 & 1 & 0 & 10 & 0 \\
\hline Picloram + & 560 & & & & & & \\
\hline 2,4-D & 1,120 & 35 & 34 & 93 & 135 & 310 & 190 \\
\hline $\operatorname{LSD}(0.05)$ & & 18 & 9 & 41 & 101 & 380 & 140 \\
\hline
\end{tabular}

${ }^{\mathrm{a}}$ Herbicide treatments were applied on August 31, 1994, and reapplied to the same plots on September 26, 1995.

Ainsworth, NE, 1994. In 1995 and 1996, fall-applied AC 263,222 controlled 100\% of the leafy spurge, which was better than control with quinclorac (Table 3). AC 263,222 at 140 and $210 \mathrm{~g} /$ ha applied only in the spring controlled no more than $65 \%$ of the leafy spurge and appeared to stimulate leafy spurge growth. In 1995, leafy spurge biomass was more than $300 \mathrm{~kg} / \mathrm{ha}$ where AC 263,222 was applied at 140 or $210 \mathrm{~g} / \mathrm{ha}$ in the spring compared with $<20 \mathrm{~kg} / \mathrm{ha}$ of biomass where AC 263,222 was applied in the fall alone or in the fall and spring. By 1996, leafy spurge biomass where AC 263,222 was applied in the fall was less than that where AC 263,222 was applied in the spring at $210 \mathrm{~g} / \mathrm{ha}$ or where no herbicide was applied. Leafy spurge density was greatest $\left(75 \mathrm{shoots} / \mathrm{m}^{2}\right)$ where AC 263,222 at $210 \mathrm{~g} /$ ha was applied only in the spring. Densities where other herbicide treatments were applied were not different from the density where no herbicides were applied.

Cool-season grass response to AC 263,222 was influenced by rate and season of application. In 1996, after two consecutive years of herbicide application, cool-season grass biomass was $2.6 \mathrm{Mg} / \mathrm{ha}$ where AC 263,222 at $140 \mathrm{~g} / \mathrm{ha}$ was applied only in the fall, which was similar to cool-season grass biomass where picloram plus 2,4-D, quinclorac, or no herbicide was applied (Table 3). In contrast, cool-season grass biomass was reduced $>55 \%$ where AC 263,222 was applied in the spring or in the fall at $280 \mathrm{~g} / \mathrm{ha}$ compared with biomass where picloram plus 2,4-D or no herbicide was applied. Reduction in cool-season grass biomass could have resulted from arrested phenological development caused by AC 263,222. At time of harvest in August 1996, cool-season grasses were vegetative in areas treated with AC 263,222 in the spring or with AC 263,222 at $280 \mathrm{~g} / \mathrm{ha}$ in the fall, whereas cool-season grasses were headed where AC 263,222 at $140 \mathrm{~g} / \mathrm{ha}$ was applied in the fall only or where no herbicide was applied. This response is similar to that observed with another imidazolinone herbicide, imazethapyr, which slowed maturation of cool-season grasses when applied in the spring (Fales et al. 1990). 
Table 3. Leafy spurge control, shoot density, and shoot biomass and cool-season grass (CSG) biomass in August 1995 and 1996 after fall and/or spring applications of herbicides on a range site near Ainsworth, NE.

\begin{tabular}{|c|c|c|c|c|c|c|c|c|c|}
\hline \multirow[b]{3}{*}{ Herbicide } & \multicolumn{7}{|c|}{ Leafy spurge } & \multirow{2}{*}{\multicolumn{2}{|c|}{$\mathrm{CSG}$}} \\
\hline & \multicolumn{2}{|c|}{ Rate } & \multicolumn{2}{|c|}{ Control } & \multirow{2}{*}{$\begin{array}{c}\text { Density } \\
1996\end{array}$} & \multicolumn{2}{|c|}{ Biomass } & & \\
\hline & Fall $^{\mathrm{a}}$ & Spring $^{b}$ & 1995 & 1996 & & 1995 & 1996 & 1995 & 1996 \\
\hline & \multicolumn{2}{|c|}{$\mathrm{g}$ ai/ha } & \multicolumn{2}{|c|}{$-\%-$} & no. $/ \mathrm{m}^{2}$ & \multicolumn{2}{|c|}{$\mathrm{kg} / \mathrm{ha}-$} & \multicolumn{2}{|c|}{$\mathrm{Mg} / \mathrm{ha}$} \\
\hline No herbicide & 0 & 0 & 0 & 0 & 19 & 120 & 130 & 3.1 & 2.3 \\
\hline AC 263,222 & 140 & 0 & 100 & 100 & 0 & 20 & 0 & 2.6 & 2.6 \\
\hline AC 263,222 & 0 & 140 & 33 & 50 & 36 & 370 & 80 & 2.5 & 1.2 \\
\hline AC 263,222 & 140 & 140 & 100 & 100 & 0 & 10 & 0 & 1.7 & 0.6 \\
\hline AC 263,222 & 210 & 0 & 100 & 100 & 1 & 10 & 10 & 1.8 & 2.2 \\
\hline AC 263,222 & 0 & 210 & 43 & 65 & 75 & 320 & 160 & 2.6 & 0.7 \\
\hline AC 263,222 & 210 & 210 & 100 & 100 & 0 & 20 & 0 & 1.1 & 0.1 \\
\hline AC 263,222 & 280 & 0 & 100 & 100 & 1 & 20 & 0 & 1.7 & 1.1 \\
\hline Quinclorac & 1,120 & 0 & 77 & 63 & 10 & 20 & 80 & 3.3 & 2.2 \\
\hline Picloram & 560 & 560 & 100 & 93 & 1 & 130 & 30 & 3.2 & 2.8 \\
\hline$+2,4-\mathrm{D}^{\mathrm{c}}$ & 1,120 & 1,120 & & & & & & & \\
\hline $\operatorname{LSD}(0.05)$ & & & 22 & 11 & 38 & 200 & 100 & 1.1 & 1.3 \\
\hline
\end{tabular}

Ainsworth, NE, 1995. The fall herbicide application main effect was significant for measured leafy spurge response variables; the spring application main effect was not significant. Fall-applied AC 263,222 controlled $>90 \%$ of the leafy spurge, regardless of rate (Table 4). The application of AC 263,222 at $70 \mathrm{~g} / \mathrm{ha}$ in the spring did not improve leafy spurge control. The fall by spring herbicide application interaction was significant only for leafy spurge shoot density. Leafy spurge density was greater at 92 shoots $/ \mathrm{m}^{2}$ where AC 263,222 at $70 \mathrm{~g} /$ ha was applied only in the spring compared to $<20$ shoots $/ \mathrm{m}^{2}$ where AC 263,222 was applied in the fall.

The spring application main effect had a significant effect on warm-season grass biomass. Herbage biomass of the dominant warm-season grass, prairie cordgrass, was reduced by spring application of AC 263,222 at $70 \mathrm{~g} /$ ha compared with prairie cordgrass that was not treated with AC 263,222 in the spring (Table 4). Prairie cordgrass exhibited symptoms (chlorotic leaves, stunting) typically associated with imidazolinone herbicide injury. 
Table 4. Leafy spurge control, shoot density, and shoot biomass and warm-season grass (WSG) shoot biomass in August 1996 after fall and/or spring applications of herbicides on a range site near Ainsworth, NE.

\begin{tabular}{|c|c|c|c|c|c|c|}
\hline \multirow[b]{2}{*}{ Herbicide } & \multicolumn{2}{|c|}{ Rate } & \multicolumn{3}{|c|}{ Leafy spurge } & \multirow[b]{2}{*}{ WSG } \\
\hline & Fall $^{\mathrm{a}}$ & Spring $^{b}$ & Control & Density & Biomass & \\
\hline & \multicolumn{2}{|c|}{$\mathrm{g} \mathrm{ai} / \mathrm{ha}$} & $\%$ & no. $/ \mathrm{m}^{2}$ & $\mathrm{~kg} / \mathrm{ha}$ & $\mathrm{Mg} / \mathrm{ha}$ \\
\hline \multicolumn{7}{|c|}{ Fall treatment main effects ${ }^{\mathrm{c}}$} \\
\hline AC 263,222 & 0 & - & 13 & 55 & 270 & 2.7 \\
\hline AC 263,222 & 140 & - & 97 & 3 & 10 & 2.2 \\
\hline AC 263,222 & 210 & - & 94 & 10 & 20 & 1.6 \\
\hline AC 263,222 & 280 & - & 99 & 1 & 0 & 2.5 \\
\hline $\operatorname{LSD}(0.05)$ & & & 12 & 23 & 160 & NS \\
\hline \multicolumn{7}{|c|}{ Spring treatment main effects ${ }^{\mathrm{d}}$} \\
\hline AC 263,222 & - & 0 & 72 & 11 & 50 & 2.7 \\
\hline AC 263,222 & - & 70 & 79 & 23 & 110 & 1.8 \\
\hline $\operatorname{LSD}(0.05)$ & & & NS & NS & NS & 0.8 \\
\hline
\end{tabular}

Hankinson, ND. Leafy spurge control was $<50 \%$ where AC 263,222 was applied only in the fall and was $0 \%$ where quinclorac at $1,120 \mathrm{~g} / \mathrm{ha}$ was applied (Table 5). In contrast, leafy spurge control was $>80 \%$ where applications of AC 263,222 were made in the fall and again in the spring. AC 263,222 at 70 or $140 \mathrm{~g} / \mathrm{ha}$ applied only in the spring provided $>65 \%$ leafy spurge control. Leafy spurge densities were $>120$ shoots $/ \mathrm{m}^{2}$ and were not influenced by AC 263,222 or quinclorac treatments. Leafy spurge biomass where AC 263,222 was applied both in the fall and spring was less than biomass on quinclorac-treated areas or where no herbicide was applied.

Herbicide treatments affected herbage biomass of the cool-season grasses, but not that of the warm-season grasses or forbs. In contrast, cool-season grass biomass was reduced $>55 \%$ by application of AC 263,222 in the spring (Table 5). Cool-season grass biomass was greater $(600 \mathrm{~kg} / \mathrm{ha})$ where AC 263,222 at $140 \mathrm{~g} / \mathrm{ha}$ was applied in the fall than where quinclorac or fall plus spring applications of AC 263,222 were made.

Tilden, NE. Fall-applied AC 263,222 provided greater leafy spurge control than picloram plus 2,4-D or no herbicide treatment (Table 6). Quinclorac provided leafy spurge control similar to fall-applied AC 263,222 at $140 \mathrm{~g} / \mathrm{ha}$ without a spring treatment, but less control than treatments that included fall and spring applications of AC 263,222. Leafy spurge control with AC 263,222 at $70 \mathrm{~g} / \mathrm{ha}$ applied only in the spring was the same as picloram plus 2,4-D. Leafy spurge density and biomass were greater where AC 263,222 at $70 \mathrm{~g} /$ ha was applied only in spring compared with picloram plus 2,4-D. Leafy spurge biomass where quinclorac or picloram plus 2,4-D was applied was not different from biomass where no herbicide was applied, but greater than biomass where AC 263,222 was applied in the fall. 
Table 5. Leafy spurge control, shoot density, and shoot biomass and cool-season grass (CSG) shoot biomass in August 1996 after fall and/or spring applications of herbicides on a range site near Hankinson, ND.

\begin{tabular}{|c|c|c|c|c|c|c|}
\hline \multirow{2}{*}{ Herbicide } & \multicolumn{2}{|c|}{ Rate } & \multicolumn{3}{|c|}{ Leafy spurge } & \multirow[b]{2}{*}{ CSG } \\
\hline & Fall $^{\mathrm{a}}$ & Spring $^{\mathrm{b}}$ & Control & Density & Biomass & \\
\hline & \multicolumn{2}{|c|}{$\mathrm{g} \mathrm{ai} / \mathrm{ha}$} & $\%$ & no. $/ \mathrm{m}^{2}$ & $\mathrm{~kg} / \mathrm{ha}$ & $\mathrm{Mg} / \mathrm{ha}$ \\
\hline No herbicide & 0 & 0 & 0 & 440 & 240 & 0.4 \\
\hline AC 263,222 & 140 & 0 & 28 & 321 & 190 & 0.6 \\
\hline AC 263,222 & 210 & 0 & 45 & 379 & 90 & 0.4 \\
\hline AC 263,222 & 280 & 0 & 50 & 233 & 130 & 0.3 \\
\hline AC 263,222 & 0 & 70 & 66 & 185 & 90 & 0.1 \\
\hline AC 263,222 & 140 & 70 & 83 & 172 & 40 & 0.2 \\
\hline AC 263,222 & 210 & 70 & 93 & 125 & 10 & 0.2 \\
\hline AC 263,222 & 280 & 70 & 94 & 152 & 20 & 0.1 \\
\hline AC 263,222 & 0 & 140 & 85 & 160 & 80 & 0.1 \\
\hline AC 263,222 & 140 & 140 & 90 & 200 & 40 & 0.3 \\
\hline AC 263,222 & 210 & 140 & 90 & 145 & 20 & 0.2 \\
\hline AC 263,222 & 280 & 140 & 98 & 147 & 10 & 0.2 \\
\hline Quinclorac & 1,120 & 0 & 0 & 279 & 260 & 0.3 \\
\hline $\operatorname{LSD}(0.05)$ & & & 10 & NS & 150 & 0.2 \\
\hline $\begin{array}{l}{ }^{a} \mathrm{~F} \text { all herbicide treat } \\
{ }^{\mathrm{b}} \text { Spring herbicide tr }\end{array}$ & $\begin{array}{l}\text { pplied } \\
\text { e appli }\end{array}$ & $\begin{array}{l}\text { tember } 2 \\
\text { Iune } 26 \text {, }\end{array}$ & & & & \\
\hline
\end{tabular}

Cool-season grass biomass was reduced by $\geq 50 \%$ where AC 263,222 at $70 \mathrm{~g} / \mathrm{ha}$ was applied in the spring (Table 6). Cool-season grass biomass from plots treated with AC 263,222 at 140 or $210 \mathrm{~g} / \mathrm{ha}$ in the fall was the same as biomass where quinclorac, picloram plus 2,4-D, or no herbicide was applied. The biomass of warm-season grasses and forbs was not affected by herbicide treatments.

In all experiments, AC 263,222 effectively controlled leafy spurge. In Nebraska, a single application of AC 263,222 in the fall at $140 \mathrm{~g} /$ ha provided $\geq 85 \%$ leafy spurge control 11 to 12 months after treatment in the fall (Tables 3, 4, and 6). At Jamestown, ND, leafy spurge control increased to almost $90 \%$ and stem density was reduced 12 months after the second consecutive fall application of AC 263,222 at $140 \mathrm{~g} /$ ha (Table 2). At Hankinson, ND, leafy spurge control was $<50 \%$ where AC 263,222 was applied in the fall, but increased to $>80 \%$ when AC 263,222 was applied again in the spring (Table 5).

Soil characteristics at Hankinson may account for the reduced level of leafy spurge control observed where AC 263,222 was applied only in the fall compared to control observed at research sites near Ainsworth, Jamestown, and Tilden. At Hankinson, the soil was a silt loam while soils at the Nebraska sites were sandy and the soil at Jamestown was a shallow loamy sand underlain by a deep sand (Table 1). Efficacy of imidazolinone herbicides has been demonstrated to be greater in coarse-textured soils than in finetextured soils (Stougaard et al. 1990). Masters et al. (1994) found that leafy spurge control with imazapyr, imazethapyr, or imazaquin was less on a site with a silty clay loam soil compared with the site where the soil was a fine sand. Perhaps repeated AC 263,222 application in the fall over consecutive years would improve leafy spurge control at Hankinson. 
Table 6. Leafy spurge control, shoot density, and shoot biomass and cool-season grass (CSG) shoot biomass in August 1996 after fall and/or spring applications of herbicides on a range site near Tilden, NE.

\begin{tabular}{|c|c|c|c|c|c|c|}
\hline \multirow{2}{*}{ Herbicide } & \multicolumn{2}{|c|}{ Rate } & \multicolumn{4}{|c|}{ Leafy spurge } \\
\hline & Fall $^{\mathrm{a}}$ & Spring $^{b}$ & Control & Density & Biomass & CSG \\
\hline & & ha & $\%$ & no. $/ \mathrm{m}^{2}$ & $\mathrm{~kg} / \mathrm{ha}$ & $\mathrm{mg} / \mathrm{ha}$ \\
\hline No herbicide & 0 & 0 & 0 & 71 & 170 & 0.7 \\
\hline AC 263,222 & 140 & 0 & 85 & 0 & 0 & 0.6 \\
\hline AC 263,222 & 210 & 0 & 100 & 0 & 0 & 0.8 \\
\hline AC 263,222 & 280 & 0 & 97 & 0 & 0 & 0.4 \\
\hline AC 263,222 & 0 & 70 & 47 & 193 & 320 & 0.3 \\
\hline AC 263,222 & 140 & 70 & 100 & .0 & 0 & 0.3 \\
\hline AC 263,222 & 210 & 70 & 100 & 0 & 0 & 0.3 \\
\hline AC 263,222 & 280 & 70 & 100 & 0 & 0 & 0.3 \\
\hline Quinclorac & 1,120 & 0 & 75 & 14 & 80 & 0.7 \\
\hline Picloram + & 560 & 0 & & & & \\
\hline 2,4-D & 1,120 & - & 50 & 35 & 100 & 0.8 \\
\hline $\operatorname{LSD}(0.05)$ & & & 17 & 80 & 150 & 0.3 \\
\hline
\end{tabular}

${ }^{\mathrm{a}}$ Fall herbicide treatments were applied on October 11, 1995.

${ }^{\mathrm{b}}$ Spring herbicide treatments were applied on June 17, 1996.

Response of vegetation growing in association with leafy spurge at the research sites was influenced primarily by season of AC 263,222 application. AC 263,222 at $140 \mathrm{~g} / \mathrm{ha}$ applied in the fall did not reduce forb or cool- and warm-season grass biomass compared with treatment with picloram plus 2,4-D, quinclorac, or no herbicide. In contrast, application of AC 263,222 in the fall and again in the spring usually reduced cool-season grass biomass.

In summary, AC 263,222 at $140 \mathrm{~g} / \mathrm{ha}$ applied in the fall provided good to excellent leafy spurge control in four of five environments, while not adversely affecting other vegetation. Leafy spurge control with AC 263,222 at $140 \mathrm{~g} / \mathrm{ha}$ applied in the fall ranged from 50 to $100 \% 11$ to 12 months after treatment and was superior to the $<30 \%$ leafy spurge control 11 months after treatment observed in previous research where other imidazolinone herbicides, imazapyr and imazethapyr, were applied in the fall at 140 or 280 $\mathrm{g} / \mathrm{ha}$ in Nebraska (Masters et al. 1994). AC 263,222 has the potential to be an alternative to picloram plus 2,4-D for leafy spurge control on rangelands in the northern Great Plains.

Research is needed to refine AC 263,222 treatment recommendations. Specifically, long-term studies are needed to ascertain the effect of repeated annual applications of AC 263,222 on leafy spurge-infested rangeland communities and to determine if it is feasible to reduce the rate of AC 263,222 applied annually or to reduce the frequency of AC 263,222 treatment while maintaining a desirable level of leafy spurge control. In addition, it is important to determine the role of AC 263,222 in integrated management systems that include other technologies, such as biological control agents, fire, and establishment of desirable competitive plant species, applied in sequences and combinations to optimize improvement of leafy spurge-infested rangelands (Masters and Nissen 1998). 


\section{Acknowledgments}

The authors thank Kevin Grams, Vincenzo Di Ilio, Kenneth Carlson, Jennifer Hoffman, and Brenda Younkin for their assistance; American Cyanamid Co. for partial support for this research; and Sidney Salzman, Rancher, and Bruce Ofe, Weed Superintendent, Antelope County, for help identifying research sites in Nebraska and Rod Lym, North Dakota State University, Robert Martin, U.S. Army Corps of Engineers, and Scott Kahan, USDI Fish and Wildlife Service for locating research sites in North Dakota.

\section{Literature cited}

Belcher, J. W. and S. D. Wilson. 1989. Leafy spurge and the species composition of a mixed-grass prairie. J. Range Manage. 42:172-175.

Dunn, P. H. 1979. The distribution of leafy spurge (Euphorbia esula) and other weedy Euphorbia spp. in the United States. Weed Sci. 27:509-516.

Fales, S. L., R. R. Hill, and R. J. Hoover. 1990. Chemical regulation of growth and forage quality of coolseason grasses with imazethapyr. Agron. J. 82:9-17.

Federer, W. T and D. Raghavarao. 1975. On augmented designs. Biometrics 31:29-35.

Kuehl, B. D. and R. G. Lym. 1997. Leafy spurge (Euphorbia esula) control with quinclorac. Weed Technol. 11:265-269.

Lym, R. G. and C. G. Messersmith. 1985. Leafy spurge control with herbicides in North Dakota: 20-year summary. J. Range Manage. 38:149-154.

Masters, R. A. and S. J. Nissen. 1998. Revegetating leafy spurge (Euphorbia esula L.)-infested grasslands with native tallgrasses. Weed Technol. 12: 381-390.

Masters R. A., R. Stritzke, and S. S. Waller. 1990. How to conduct a prescribed burn and prescribed burning checklist. Nebraska Cooperative Extension Service. EC 90-121.

Masters, R. A., R. N. Stougaard, and S. J. Nissen. 1994. Leafy spurge (Euphorbia esula) control with fallapplied imazapyr, imazaquin, and imazethapyr. Weed Technol. 8:58-63.

Nissen, S. J., R. A. Masters, and R. N. Stougaard. 1994. Imazethapyr absorption and fate in leafy spurge (Euphorbia esula). Weed Sci. 42:158-162.

Nissen, S. J., R. A. Masters, W. M. Thompson, and R. N. Stougaard. 1995. Absorption and fate of imazapyr in leafy spurge (Euphorbia esula). Pestic. Sci. 45:325-329.

Ott, L. 1977. An Introduction to Statistical Methods and Data Analysis. Belmont, CA: Duxbury Press.

[SAS] Statistical Analysis Systems. 1990. SAS/STAT User's Guide. Version 6, 4th ed, Volume 2. Cary, NC: Statistical Analysis Systems Institute.

Stougaard, R. N., P. J. Shea, and A. R. Martin. 1990. Effect of soil type and pH on adsorption, mobility, and efficacy of imazaquin and imazethapyr. Weed Sci. 38:67-73.

Thompson, W. M., S. J. Nissen, and R. A. Masters. 1996. Adjuvant effects on imazethapyr, 2,4-D, and picloram absorption by leafy spurge (Euphorbia esula). Weed Sci. 44:469-475.

Thompson, W. M., S. J. Nissen, and R. A. Masters. 1998. AC 263,222 absorption and fate in leafy spurge (Euphorbia esula). Weed Sci. In press.

Page 12 of 12 